\title{
CUSTOMER SATISFACTION IN THE CONTEXT OF BRAND POSITIONING IN SERVICE SECTOR: A CASE STUDY OF STARBUCKS IN ANKARA
}

\author{
Ömer YURTSEVEN ${ }^{1}$ \\ Serkan ŞANDIR ${ }^{2}$
}

\author{
Received Date (Başvuru Tarihi): 13/07/2018 \\ Accepted Date (Kabul Tarihi): 01/08/2018 \\ Published Date (Yayın Tarihi): 02/09/2018
}

\begin{abstract}
It has become quite important to create a brand and increase brand awareness in today's global world where the interaction among societies have increased tremendously. Brands that position themselves on a worldwide basis while keeping their own cultural traits, increase their chances of success. The main purpose of this study is to investigate the impact of customer satisfaction and social activities on brand positioning. For this, a survey is conducted in one of the most successful service sector firms, Starbucks. Its customers' satisfaction in relation to brand positioning in Turkish market specifically in Ankara has been explored. The results show that there is a meaningful relationship between customer satisfaction and brand positioning of Starbucks in Ankara. Participation by customers in social activities has also proven to have a positive relationship with brand positioning.
\end{abstract}

Keywords: Customer Satisfaction, Brand Positioning, Service Sector.

JEL Codes: M11, M31

\section{HIZMET SEKTÖRÜNDE MARKA KONUMLANDIRMA BAĞLAMINDA TÜKETİCI TATMINI: ANKARA STARBUCKS ÇALIŞMASI}

\section{$\ddot{O} \mathbf{Z}$}

Toplumlar arasındaki etkileşimin her geçen gün arttı̆̆ günümüz küreselleşen dünyasında marka yaratmak ve bu markanın dünya üzerinde bilinirliliğini artırmak önemli hale gelmiştir. Kendi kültürünü ve karakterini yansıtarak aynı zamanda dünya çapında dünyanın gerekliliklerini yerine getirerek kendisini konumlayabilen markaların başarı oranı oldukça yüksektir. Bu çalışmanın temel amacı, müşteri tatmini ve sosyal sktivitelerin marka konumlandırılmasına olan etkisini incelemektir. Bu amaçla hizmet sektöründe faaliyet gösteren en başarılı markalardan biri olan Starbucks örnek alınmıştır. Çalışmanın sonucunda Türkiye pazarında, özellikle de Ankara'daki müşterilerinin tatmini ile Starbucks'ın konumlandırlması arasında anlamlı bir ilişki saptanmıştır. Aynı zamanda sosyal aktivitelere müşteri katılımının da marka konumlandırılması ile ilişkili olduğu görülmüştür.

Anahtar Kelimeler: Müşteri Memnuniyeti, Marka Konumlandırma, Hizmet Sektörü.

JEL Kodlart: M11, M31

\footnotetext{
${ }^{1}$ Asst. Prof., Çankaya University, yurtseven@ cankaya.edu.tr

${ }^{2}$ H.Y. Proje A.Ş., serkan.sandir@gmail.com
} 


\section{INTRODUCTION}

In today's global world, the boundaries, to some extent, have disappeared, the role and importance of international trade have increased and economic, political, social relations among nations strengthened. Due to the increasing convergence of countries, increasing dependence on each other has increased and limited resources have made trade between them inevitable. For this reason, having an international identity for companies has become a vital proposition in terms of recognition and aspiring confidence. In order to survive in today's competitive markets, it is vital to understand the brand concept, how to position the brand, and to understand and fulfill to the fullest, the main requirements of international trade.

In this paper, brand concept is explained thoroughly and the elements of the brand (specifically brand positioning) are examined. The relationship between customer satisfaction and brand positioning is taken into consideration. For this purpose, a survey is conducted in one of the most successful service sector firms, namely Starbucks. Its customers' satisfaction in relation to the brand positioning in Turkish market specifically in Ankara is investigated. In addition, participation in social activities also has been taken into consideration in the study. To this end, two hypotheses have been generated:

H1: There is a meaningful positive relationship between customer satisfaction and brand positioning.

H2: There is a meaningful positive relationship between social activities and brand positioning.

\section{LITERATURE REVIEW}

Brand positioning is usually as "the act of designing the company's offering and image to occupy a distinctive place in the mind of the target market" (Keller, 1993). In other words, brand positioning describes how a brand is different from its competitors and where, or how, it sits in customers' minds. A brand positioning strategy therefore involves creating brand associations in customers' minds to make them perceive the brand in a more favorable way.

In today's highly competitive world, brand positioning offers companies a road map to differentiate themselves from their competitors. Farquhar (1989) looked into the factors that influence buyer purchasing behavior and concluded that companies that can create an equity (added value) in consumers' mind will have a greater chance of success. 
Aaker D.A. (1991), one of the pioneers modern branding, contended that brand positioning would be more beneficial with brand equity which has abstract features such as brand image, brand identity and the like. He also stressed significance of positioning of a brand in terms of both by rational benefits such as price and emotional factors i.e. shopping experience.

This idea of brand equity and its influence on consumer is investigated by Keller, K. (1993). He characterizes brand positioning as "the act of designing the company's offer and image so that it occupies a distinct and valued place in the target customers minds." $\mathrm{He}$ established a customer based brand equity (CBBE) conceptual model and found that customers who have a favorable image of the company in their minds are more likely to act favorably to the company's marketing mix activities. He benefited from a Park et.al (1986) study which used brand concept management (BCM) that examined the changing role of brand image over time.

These studies show that companies that can position their products successfully in consumers' minds and satisfy them started to get ahead of their rivals. Chaudhuri and Holbrook (2001) investigated the effects of brand trust and brand effect on consumer purchasing behavior. They concluded that brand trust and brand affect led to purchase loyalty, this in turn, contributed to greater market share. Mortensen et al. (2000) stated that customer satisfaction is an important tool in the improvement of the firm's performance. Bitner and Zeithaml (2003) described customer satisfaction as how well the good or service meet customers' needs and expectations.

Services as opposed to goods are intangible. Kotler and Keller (2013) suggested that: i) service customers depend more on rumor than advertising, ii) they judge quality based on price, provider and physical hints, iii) they are extremely loyal to service providers that satisfy them and finally iv) high switching costs make it difficult for competitors to lure customers away. They stress importance of customer satisfaction as a strategic component in service sector companies.

Further studies explored the brand concept and its components as Kim et al. (2003), Atılgan et al. (2005) and Pappu, et al. (2005).

Brand positioning and its impact on consumers has been one of the most important concepts in marketing. Jacoby and Chestnut (1978) described brand positioning in terms of prejudiced, behavioral responses which are conveyed over time through decision making, with respect to one or more brands. Nanji (2017) stressed that consumers felt more emotionally connected to brands that seem caring about people. 
MiRan et.al. (2015) asserted that customer satisfaction and delight influenced the positioning positively in the hospitality industry. Deng et al. (2010) studied the determinants of customer satisfaction and brand positioning. They found that perceived customer value both functional and emotional has been influential in achieving customer satisfaction. Flint et.al. (2011) examined the relationship among customer value anticipation, customer satisfaction and brand positioning. They stated that customer value expectation acts as a strong motivator for satisfaction and positioning.

The underlying theme in all of these studies is that customer satisfaction eventually lead to effective brand positioning. This study investigates these relationships taking Starbucks, Ankara as an example. For the purpose of our study customer satisfaction and social activities were taken to be the key factors that contribute to brand positioning. Throughout the literature we encountered three commonly used measures for customer satisfaction namely overall quality, satisfaction with the brand and recommendation to others (see Hauscknecht, 1990; Jones and Sasser, 1995; Levesque and McDougall, 1996; Naser et al., 1999 and Jamal and Goode, 2001). These measures are included in our survey as varying questions in order to capture the demographic profile and tendencies of the respondents.

\section{POSITIONING OF STARBUCKS}

Starbucks Corporation was founded in 1971 in Seattle, WA., USA. Its product mix includes variety of coffees, teas and fresh food items. It also sells different coffee and tea products and licenses its trademark through licensing agreements. In its business portfolio there are other companies including Teavana, Tazo, Seattle's Best Coffee, Starbucks VIA, Starbucks Refreshers, Evolution Fresh, La Boulange and Verismo.

Starbucks has positioned itself as an upscale brand and presented its offerings as high quality premium products at high prices. (Starbucks, 2013). It has long employed product differentiation strategy successfully. Geographically, it operates in USA, Canada, Latin America, Europe, Middle East, Africa, China and Asia Pacific Region and chooses urban centers. The organization at first, focused on youth market. However, with quick development and extension, target market expanded. Today, Starbucks targets customers of all ages who are willing to pay high prices for premium products. Its target market includes both male and female professionals, students and employees. Loyal customers are its one of the main staples. It also serves low-calorie food and drinks for health-conscious customers. (Geereddy, 2013). 


\section{DATA AND RESULTS}

Data were collected through face to face survey method. The survey was conducted among Starbucks users over 18 who reside in Ankara and it was carried out at Starbucks stores located in different districts of Ankara. They can be ordered as follows; Panora AVM, Taurus AVM, Forum Ankara AVM, Atlantis AVM, Kızlay AVM and Bilkent Reserve. The survey was conducted entirely within Starbucks stores and at different locations in Starbucks with 157 random Starbucks users. The reasons for this is to make sure that surveyor are Starbucks users and that they have experienced the Starbucks culture. So, it is aimed to raise the reliability of the questionnaire. Another cause is the observation of the differences between the responses of the questions that is given by people who are located in different regions and in different living standards.

The information required for the study was prepared by a two-part questionnaire. The first part consisted of questions on which personal information were obtained and the second part included questions to gather the necessary data in accordance with the objective of the study. A total of 30 questions were asked of the respondents and they were expected to answer each question based on a 1 to 5 scale. They were 1: totally disagree; 2: disagree; 3: neither agree nor disagree; 4: agree and 5: totally agree. The details of the questions were given in Tables 27. The details of the questions are mentioned in the Tables 2-7. Our questionnaire was based on the coffee shop survey of Hayes (see Hayes, 1998, Chapter 8). In his book, Hayes cited a survey conducted with 100 people using the scale we have exactly used. Hayes' survey was for a coffee company named Wake Inc. and the questions were about product variety, friendliness, special products, shows and publications issues. In preparation of our questionnaire we have also utilized one of the most cited articles for coffee sector (see Waxman, 2008). He emphasized the importance of design, socialization, networking and sense of community for brand positioning. We prepared our questions in accordance with these studies and in addition we paid a particular importance to social activities.

After the questionnaire was fully prepared, the intelligibility of the questions and the reactions given to the questions were tested on a scale of over twenty. In addition, consultations were held with the Starbucks store managers in selected regions. As a result of these questionnaire analyzes, Cronbach Alpha reliability of 0.825 was reached, which is highly reliable in the literature.

Of the 157 randomly chosen subjects 80 were women, 77 were men. Majority of coffee users were between the ages of 26 and 34. They had Bachelor degrees and frequented the 
Starbucks shops in Ankara at least twice or three times a week. Details are portrayed in Table $1:$

Table 1: How frequently respondents visit Starbucks

\begin{tabular}{|c|c|c|}
\hline & Number & Percent \\
\hline Frequency & & \\
\hline Twice a day & 7 & 4,5 \\
\hline Once a day & 30 & 19,1 \\
\hline 2-3 times a week & 53 & 33,8 \\
\hline Once a week & 42 & 26,8 \\
\hline Less frequently & 25 & 15,9 \\
\hline
\end{tabular}

In order to address the adequacy and reliability of the sample size we refer to the pioneering study of Jamal and Goode (2001). They used a sample size of 118 and mentioned that in order to ensure the sampling distribution to be normally distributed the sample size has to be greater than 30 .

IBM SPSS software program was used to analyze the responses given by customers answering the questionnaire.

The model of the study incorporates demographic factors and a product based factor (i.e. customer satisfaction and social activities) as exogenous and brand positioning as endogenous variables which are shown in Figure 1.

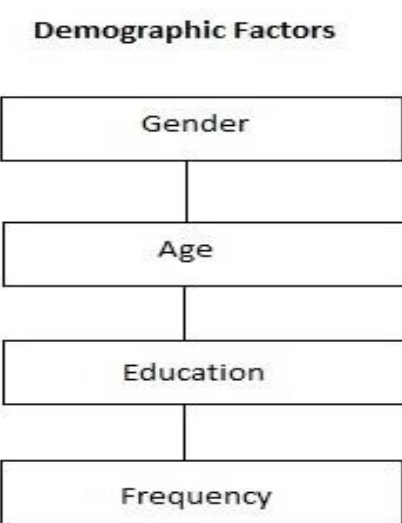

Product Based Factors

Endogenous Variable

Figure 1: The model 
In order to test $\mathrm{H} 1$ and $\mathrm{H} 2$ we applied Pearson correlation coefficient tests. Correlation between customer satisfaction and brand positioning that is cited in the first hypothesis was tested for validity and accuracy as can be viewed in Tables, 2 to 7 .

Table 2: Correlation test for $\mathrm{H} 1$

\begin{tabular}{|c|c|c|c|c|c|}
\hline \multicolumn{6}{|c|}{ Correlations } \\
\hline & & Music & $\begin{array}{l}\text { Product } \\
\text { Variety }\end{array}$ & Design & Atmosphere \\
\hline \multirow{3}{*}{ Music } & Corr. & 1 & $0,557 * *$ & $0,474 * *$ & $0,482 * *$ \\
\hline & Sig. & & 0,000 & 0,000 & 0,000 \\
\hline & $\mathrm{N}$ & 157 & 157 & 157 & 157 \\
\hline \multirow{3}{*}{$\begin{array}{l}\text { Product } \\
\text { Variety }\end{array}$} & Corr. & $0,557 * *$ & 1 & $0,388 * *$ & $0,495 * *$ \\
\hline & Sig. & 0,000 & & 0,003 & 0,000 \\
\hline & $\mathrm{N}$ & 157 & 157 & 157 & 157 \\
\hline \multirow{3}{*}{ Design } & Corr. & $0,474 * *$ & $0,388 * *$ & 1 & $0,708 * *$ \\
\hline & Sig. & 0,000 & 0,000 & & 0,000 \\
\hline & $\mathrm{N}$ & 157 & 157 & 157 & 157 \\
\hline \multirow{3}{*}{ Atmosphere } & Corr. & $0,482 * *$ & $0,495 * *$ & $0,708 * *$ & 1 \\
\hline & Sig. & 0,000 & 0,000 & 0,000 & \\
\hline & $\mathrm{N}$ & 157 & 157 & 157 & 157 \\
\hline
\end{tabular}

- The correlation between "The variety of Starbucks coffees and their food is satisfactory" and "The music at Starbucks stores provides a relaxing and peaceful environment" are valid because the significance percentage of 0,000 which is less than 0,05 . So the correlation between these two factors is $55 \%$ with the positive direction.

- The correlation between "The decoration of the Starbucks stores is impressive and visually very well designed." and "The music at Starbucks stores provides a relaxing and peaceful environment" are valid because the significance percentage of 0,000 which is less than 0,05 . So the correlation between these two factors is $47 \%$ with the positive direction.

- The correlation between "At Starbucks stores, the atmosphere of the products, the employees, the decoration as a whole is appealing" and "The music at Starbucks stores provides a relaxing and peaceful environment" are valid because the significance percentage of 0,000 which is less than 0,05 . So the correlation between these two factors is $48 \%$ with the positive direction. 
- The correlation between "The variety of Starbucks coffees and their food is satisfactory" and "The decoration of the Starbucks stores is impressive and visually very well designed" are valid because the significance percentage of 0,000 which is less than 0,05 . So the correlation between these two factors is $38 \%$ with the positive direction.

- The correlation between "The variety of Starbucks coffees and their food is satisfactory" and "At Starbucks stores, the atmosphere of the products, the employees, the decoration as a whole is appealing" are valid because the significance percentage of 0,000 which is less than 0,05 . So the correlation between these two factors is $49 \%$ with the positive direction.

- The correlation between "At Starbucks stores, the atmosphere of the products, the employees, the decoration as a whole is appealing" and "The decoration of the Starbucks stores is impressive and visually very well designed" are valid because the significance percentage of 0,000 which is less than 0,05 . So the correlation between these two factors is $70 \%$ with the positive direction.

Table 3: Correlation test for $\mathrm{H} 1$

\begin{tabular}{|c|c|c|c|c|c|}
\hline \multicolumn{6}{|c|}{ Correlations } \\
\hline & & $\begin{array}{c}\text { Impressive } \\
\text { Smell }\end{array}$ & Souvenirs & Self service & Internet \\
\hline \multirow{3}{*}{$\begin{array}{c}\text { Impressive } \\
\text { Smell }\end{array}$} & Corr. & 1 & 0,085 & 0,144 & 0,004 \\
\hline & Sig. & & 0,288 & 0,071 & 0,964 \\
\hline & $\mathrm{N}$ & 157 & 157 & 157 & 157 \\
\hline \multirow{3}{*}{ Souvenirs } & Corr. & 0,085 & 1 & $0,340 * *$ & $0,188 *$ \\
\hline & Sig. & 0,288 & & 0,000 & 0,018 \\
\hline & $\mathrm{N}$ & 157 & 157 & 157 & 157 \\
\hline \multirow{3}{*}{ Self service } & Corr. & 0,144 & $0,340 * *$ & 1 & $0,177 *$ \\
\hline & Sig. & 0,071 & 0,000 & & 0,027 \\
\hline & $\mathrm{N}$ & 157 & 157 & 157 & 157 \\
\hline \multirow{3}{*}{ Internet } & Corr. & 0,04 & $0,188^{*}$ & $0,177 *$ & 1 \\
\hline & Sig. & 0,964 & 0,018 & 0,027 & \\
\hline & $\mathrm{N}$ & 157 & 157 & 157 & 157 \\
\hline
\end{tabular}

- The correlation between "Starbucks stores have an internet connection with printed and visual brochures that I can follow daily developments" and "I like the self-service concept 
in Starbucks stores" are valid because the significance percentage of 0,02 which is less than 0,05 . So the correlation between these two factors is $17 \%$ with the positive direction.

- The correlation between "At Starbucks stores, the atmosphere of the products, the employees, the decoration as a whole is appealing" and "The decoration of the Starbucks stores is impressive and visually very well designed" are valid because the significance percentage of 0,000 which is less than 0,05 . So the correlation between these two factors is $70 \%$ with the positive direction.

- The correlation between "At Starbucks stores, the atmosphere of the products, the employees, the decoration as a whole is appealing" and "The decoration of the Starbucks stores is impressive and visually very well designed" are valid because the significance percentage of 0,000 which is less than 0,05 . So the correlation between these two factors is $70 \%$ with the positive direction.

Table 4: Correlation test for $\mathrm{H} 1$

\begin{tabular}{|c|c|c|c|c|c|}
\hline \multicolumn{6}{|c|}{ Correlations } \\
\hline & & Developments & $\begin{array}{c}\text { Good } \\
\text { service }\end{array}$ & Needs & Time spent \\
\hline \multirow{3}{*}{ Developments } & Corr. & 1 & $0,208 * *$ & $0,261 * *$ & 0,036 \\
\hline & Sig. & & 0,009 & 0,001 & 0,659 \\
\hline & $\mathrm{N}$ & 157 & 157 & 157 & 157 \\
\hline \multirow{3}{*}{ Good service } & Corr. & $0,208 * *$ & 1 & $0,170^{*}$ & $0,379 * *$ \\
\hline & Sig. & 0,009 & & 0,033 & 0,000 \\
\hline & $\mathrm{N}$ & 157 & 157 & 157 & 157 \\
\hline \multirow{3}{*}{ Needs } & Corr. & $0,261 * *$ & $0,170 *$ & 1 & 0,057 \\
\hline & Sig. & 0,001 & 0,033 & & 0,477 \\
\hline & $\mathrm{N}$ & 157 & 157 & 157 & 157 \\
\hline \multirow{3}{*}{ Time spent } & Corr. & 0,036 & $0,379 * *$ & 0,057 & 1 \\
\hline & Sig. & 0,659 & 0,000 & 0,477 & \\
\hline & $\mathrm{N}$ & 157 & 157 & 157 & 157 \\
\hline
\end{tabular}

- The correlation between "I get very good service at Starbucks" and "I follow the latest developments of Starbucks on the website of the brand" are valid because the significance percentage of 0,009 which is less than 0,05 . So the correlation between these two factors is $20 \%$ with the positive direction. 
- The correlation between "Starbucks meets my coffee drinking and socializing needs" and "I follow the latest developments of Starbucks on the website of the brand" are valid because the significance percentage of 0,001 which is less than 0,05 . So the correlation between these two factors is $26 \%$ with the positive direction.

- The correlation between "I get very good service at Starbucks" and "Starbucks meets my coffee drinking and socializing needs" are valid because the significance percentage of 0,03 which is less than 0,05 . So the correlation between these two factors is $17 \%$ with the positive direction.

- The correlation between "I get very good service at Starbucks" and "I can say that time spent in Starbucks is a productive and enjoyable time" are valid because the significance percentage of 0,000 which is less than 0,05 . So the correlation between these two factors is $37 \%$ with the positive direction.

Table 5: Correlation test for $\mathrm{H} 2$

\begin{tabular}{|c|c|c|c|c|c|}
\hline \multicolumn{6}{|c|}{ Correlations } \\
\hline & & Lifestyle & Happiness & NGOs & $\begin{array}{l}\text { Family } \\
\text { member }\end{array}$ \\
\hline \multirow{3}{*}{ Lifestyle } & Corr. & 1 & $0,338 * *$ & 0,070 & $0,378 * *$ \\
\hline & Sig. & & 0,000 & 0,384 & 0,000 \\
\hline & $\mathrm{N}$ & 157 & 157 & 157 & 157 \\
\hline \multirow{3}{*}{ Happiness } & Corr. & $0,338 * *$ & 1 & 0,038 & $0,323 * *$ \\
\hline & Sig. & 0,000 & & 0,637 & 0,000 \\
\hline & $\mathrm{N}$ & 157 & 157 & 157 & 157 \\
\hline \multirow{3}{*}{ NGOs } & Corr. & 0,070 & 0,038 & 1 & $0,234 * *$ \\
\hline & Sig. & 0,384 & 0,637 & & 0,003 \\
\hline & $\mathrm{N}$ & 157 & 157 & 157 & 157 \\
\hline \multirow{3}{*}{$\begin{array}{l}\text { Family } \\
\text { member }\end{array}$} & Corr. & $0,378 * *$ & $0,323 * *$ & $0,234 * *$ & 1 \\
\hline & Sig. & 0,000 & 0,000 & 0,003 & \\
\hline & $\mathrm{N}$ & 157 & 157 & 157 & 157 \\
\hline
\end{tabular}

- The correlation between "I feel relieved and happy in Starbucks stores." And "Visiting the Starbucks stores changed my lifestyle and became a part of my life" are valid because the significance percentage of 0,000 which is less than 0,05 . So the correlation between these two factors is $33 \%$ with the positive direction. 
- The correlation between "Visiting the Starbucks stores changed my lifestyle and became a part of my life." and "Visiting this store makes me think I am part of the charitable Starbucks family." are valid because the significance percentage of 0,000 which is less than 0,05 . So the correlation between these two factors is $37 \%$ with the positive direction.

- The correlation between "Visiting this store makes me think I am part of the charitable Starbucks family." and "I feel relieved and happy in Starbucks stores." are valid because the significance percentage of 0,000 which is less than 0,05 . So the correlation between these two factors is $32 \%$ with the positive direction.

- The correlation between "Visiting this store makes me think I am part of the charitable Starbucks family" and "I appreciate the social responsibility projects carried out by Starbucks stores" are valid because the significance percentage of 0,003 which is less than 0,05 . So the correlation between these two factors is $23 \%$ with the positive direction.

Table 6: Correlation test for $\mathrm{H} 2$

\begin{tabular}{|c|c|c|c|c|c|}
\hline \multicolumn{6}{|c|}{ Correlations } \\
\hline & & $\begin{array}{c}\text { Internet } \\
\text { Connections }\end{array}$ & $\begin{array}{l}\text { Feeling } \\
\text { Happy }\end{array}$ & Appreciate & $\begin{array}{l}\text { Becoming } \\
\text { Lifestyle }\end{array}$ \\
\hline \multirow{3}{*}{$\begin{array}{c}\text { Internet } \\
\text { Connections }\end{array}$} & Corr. & 1 & $0,338 * *$ & 0,070 & $0,378 * *$ \\
\hline & Sig. & & 0,000 & 0,384 & 0,000 \\
\hline & $\mathrm{N}$ & 157 & 157 & 157 & 157 \\
\hline \multirow{3}{*}{$\begin{array}{l}\text { Feeling } \\
\text { Happy }\end{array}$} & Corr. & $0,338 * *$ & 1 & 0,038 & $0,323 * *$ \\
\hline & Sig. & 0,000 & & 0,637 & 0,000 \\
\hline & $\mathrm{N}$ & 157 & 157 & 157 & 157 \\
\hline \multirow{3}{*}{ Appreciate } & Corr. & 0,070 & 0,038 & 1 & $0,234 * *$ \\
\hline & Sig. & 0,384 & 0,637 & & 0,003 \\
\hline & $\mathrm{N}$ & 157 & 157 & 157 & 157 \\
\hline \multirow{3}{*}{$\begin{array}{l}\text { Becoming } \\
\text { Lifestyle }\end{array}$} & Corr. & $0,378 * *$ & $0,323 * *$ & $0,234 * *$ & 1 \\
\hline & Sig. & 0,000 & 0,000 & 0,003 & \\
\hline & $\mathrm{N}$ & 157 & 157 & 157 & 157 \\
\hline
\end{tabular}

- The correlation between "I feel relieved and happy in Starbucks stores" and "visiting the Starbucks stores changed my lifestyle and became a part of my life" is valid because of the significance percentage of 0,000 which is less than 0,05 . So, the correlation between these two factors is 0,33 . 
- The correlation between "visiting the Starbucks stores changed my lifestyle and became a part of my life" and "visiting this store makes me think I am part of the charitable Starbucks family" is valid because of the significance percentage 0,000 which is less than 0,05 . The correlation between these two factors is 0,37 .

- The correlation between "visiting this store makes me think I am part of the charitable Starbucks family" and "I feel relieved and happy in Starbucks stores" is valid because the of significance percentage of 0,000 which is less than 0,05 . So, the correlation between these two factors is 0,32 .

- The correlation between "visiting this store makes me think I am part of the charitable Starbucks family" and "I appreciate the social responsibility projects carried out by Starbucks stores" is valid because of the significance percentage of 0,003 which is less than 0,05 . The correlation between these two factors is 0,23.

Table 7: Correlation test for $\mathrm{H} 2$

\begin{tabular}{|c|c|c|c|c|c|}
\hline \multicolumn{6}{|c|}{ Correlations } \\
\hline & & $\begin{array}{l}\text { Starbucks } \\
\text { Card }\end{array}$ & Loyalty & Experience & $\begin{array}{c}\text { Social } \\
\text { Responsibility }\end{array}$ \\
\hline \multirow{3}{*}{$\begin{array}{l}\text { Starbucks } \\
\text { Card }\end{array}$} & Corr. & 1 & $0,226 * *$ & $0,412 * *$ & $0,189 *$ \\
\hline & Sig. & & 0,004 & 0,000 & 0,018 \\
\hline & $\mathrm{N}$ & 157 & 157 & 157 & 157 \\
\hline \multirow{3}{*}{ Loyalty } & Corr. & $0,226 * *$ & 1 & 0,122 & 0,024 \\
\hline & Sig. & 0,004 & & 0,129 & 0,765 \\
\hline & $\mathrm{N}$ & 157 & 157 & 157 & 157 \\
\hline \multirow{3}{*}{ Experience } & Corr. & $0,412 * *$ & 0,122 & 1 & $0,309 * *$ \\
\hline & Sig. & 0,000 & 0,129 & & 0,000 \\
\hline & $\mathrm{N}$ & 157 & 157 & 157 & 157 \\
\hline \multirow{3}{*}{$\begin{array}{c}\text { Social } \\
\text { Responsibility }\end{array}$} & Corr. & $0,189 *$ & 0,024 & $0,309 * *$ & 1 \\
\hline & Sig. & 0,018 & 0,765 & 0,000 & \\
\hline & $\mathrm{N}$ & 157 & 157 & 157 & 157 \\
\hline
\end{tabular}

- The correlation between "I think I am a loyal customer of Starbucks" and "the card of Starbucks given to its customers makes me feel special and boosts my loyalty" is valid because the significance percentage of 0,004 which is less than 0,05 . So, the correlation between these two factors is 0,22 . 
- The correlation between "the card of Starbucks given to its customers makes me feel special and boosts my loyalty" and "I have a lot of physical or intellectual experience at Starbucks stores" is valid because of the significance percentage of 0,000 which is less than 0,05 . So, the correlation between these two factors is 0,41 .

- The correlation between "the card of Starbucks given to its customers makes me feel special and boosts my loyalty" and "I appreciate the social responsibility projects carried out by Starbucks stores" is valid because of the significance percentage 0,01 which is less than 0,05 . The correlation between these two factors is 0,18 .

- The correlation between "I appreciate the social responsibility projects carried out by Starbucks stores" and "I have a lot of physical or intellectual experience at Starbucks stores" is valid because of the significance percentage 0,000 which is less than 0,05 . So the correlation between these two factors is 0,30 .

The increasing competition in the service sector has made it very clear that the companies that can make a difference in consumers' minds are more likely to get ahead of their competitors. Starbucks, with their effective employee training programs, product variety, and numerous stores at different convenient locations can be a good example of a service company that uses brand positioning to their advantage. We, therefore decided to investigate the impact of customer satisfaction on brand positioning through a study of Starbucks. As customer recommendation is a lot more important in service sector than in other sectors, we included this phenomenon in our survey.

Our results demonstrate that customer satisfaction is a vital instrument for brand positioning. Under the first hypothesis it has been found that the atmosphere and decoration in Starbucks stores is the most highly correlated factors. We have also evidence that there are some other factors such as music played at Starbucks stores and variety of products offered which are not only correlated among themselves but also correlated with atmosphere and decoration. Yet, the correlation coefficients are smaller. Another finding is the significant pairwise correlation between souvenirs, self-service and internet, however, coefficients are very small. Again there is significant but small correlation between good service, socialization needs and time spent in stores.

In addition, under this second hypothesis we encountered small but meaningful correlations between lifestyle and happiness, lifestyle and becoming a family member, NGOs 
and becoming a family member, internet and happiness, internet and lifestyle and appreciation and lifestyle.

\section{CONCLUSION}

Competitive service sector companies are increasingly using excellent customer service to separate themselves from their competitors. Within this context, satisfying their customers has become an utmost concern for most of them. Strong brands have been trying to evoke both rational and emotional responses from their customers in the positioning of their brands for some time now. To this end, creating loyal customers has been an important element in relationship marketing. Firms that are able to satisfy their customers have become more successful in creating brand positioning for themselves. Brand positioning is the most important factor in the prediction of customers' repeat purchase decisions and satisfied customers have a greater tendency to become repeat customers. Repeat customers are especially important in service sector. As service sector companies, by definition, offer intangible products, therefore recommendation is one of the key factors for their positioning strategies. They may act as "brand ambassadors" in referring the brand to other customers at little or no cost.

The findings of this study confirms that customer satisfaction is associated with brand positioning. Additionally, there is a valid relationship between social activities and brand positioning. The study was confined to Ankara. However, based on the existing literature on the subject, along with this paper's findings, it may not be unreasonable to assume that service firms that can position their brands more successfully in their customers' minds using brand loyalty and sponsored activities will reap greater benefits than their rivals.

As this study confined itself in Ankara only, the reported findings might not be applicable for the entire Starbucks stores. More precise results can be obtained when the same survey is conducted in various cities or countries in order which will overcome this limitation. 


\section{REFERENCES}

Aaker, D.A. (1991), Managing brand equity; capitalizing on the value of a brand name. The Free Press, New York, N.Y.

Atılgan, E., G. Aksoy, G. and S. Sakınc1 (2005), "Determinants of the Brand Equity: A verification approach in the beverage industry in Turkey". Marketing Intelligence and Planning, 237-248.

Bitner, M.J. and V.A. Zeithaml (2003), Service Marketing. Tata McGraw-Hill, New Delhi.

Chaudhuri, A. and M. B. Holbrook (2001), "The chain effects from brand trust and brand affect to brand performance: the role of brand loyalty", Journal of Marketing 65 (2), 81-92.

Deng Z., Y. Lu, K. K. Wei and J. Zhang (2010), "Understanding customer satisfaction and loyalty: an empirical study of mobile instant messages in China", International Journal of Information management, 30 (4), 289-300.

Farquhar, P. (1989), “Managing brand equity”, Marketing Research, 1 (3), 24-33.

Flint, D.J.C., P.J. Blocker and P.J. Blocker, Jr. (2011), "Customer value anticipation, customer satisfaction and loyalty; An empirical examination”, Industrial Marketing Management, 40 (2), 219-230.

Hayes, B. (2008), Measuring Customer Satisfaction and Loyalty. Survey Design, Use, and Statistical Analysis Methods, ASQ Quality Press, Milwaukee, Wisconsin

Hausknecht, D. (1990), "Measurement Scales in Consumer Satisfaction/Dissatisfaction”. Journal of Consumer Satisfaction, Dissatisfaction and Complaining Behaviour 3: 1-11.

Jacoby, J. and R. Chestnut, (1978), Brand loyalty measurement and management. Wiley, New York, NY.

Jamal, A. and M.H. Goode, (2001), "Consumers and brands: a study of the impact of self-image congruence on brand preference and satisfaction”, Marketing Intelligence and Planning, 19 (7) 482 - 492.

Jones, T. O., and W. E. Sasser Jr. (1995), “Why Satisfied Customers Defect”. Harvard Business Review 73 (6).

Keller, K. (1993), “Conceptualizing, Measuring, and Managing Customer-Based Brand Equity”, Journal of Marketing, 1-20.

Kim, H., W. G. Kim and J. A. An (2003), “The effect of consumer-based brand equity on firms' financial performance", The Journal of Consumer Marketing, 20 (4-5), 335-351.

Kotler, P. and K.L. Keller (2013) Marketing Management, Pearson, Upper Saddle River, New Jersey.

Levesque, T. and G.H.G. McDougall, (1996), "Determinants of customer satisfaction in retail banking", International Journal of Bank Marketing, 14 (7), 12-20.

MiRan, K., C.A. Vogt and B.J. Knutson (2015), "Relationship among customer satisfaction, delight and loyalty in the hospitality industry”, Journal of Hospitality and Tourism Research, 39 (2), 170-197.

Mortensen, A., L. Gronholdt and K. Kristensen (2000), "The drivers of customer satisfaction and loyalty: Crossindustry findings from Denmark”, Total Quality Management, 11, 544-553

Nanji, A. (2017), What emotionally connects consumers to brands? www.customerthermometer.com

Naser, K., J., Ahmad and A, Khalid. (1999). "Islamic banking: A study of customer satisfaction and preferences in Jordan”. International Journal of Bank Marketing, 17, 135-151.

Pappu, R., P. Qester and R. Cooksey (2005), "Consumer-based brand equity: improving the measurementempirical evidence", Journal of Product and Brand Management, 143-154.

Park, C. W., B. J. Jaworski and MacInnis, D. J. (1986), "Strategic Brand Concept Management. Journal of Marketing", 50, 135-145.

Waxman, L. (2008), “The Coffee Shop: Social and Physical factors Influencing Place Attachment. Journal of Interior Design", 31 (3), 35-53. 